\title{
Exchange conjunctival autograft in double pterygium
}

\author{
Sharma VK ${ }^{1}$, Verma $A^{2}$, Samuel $E^{3}$, Palod $S^{4}$ \\ ${ }^{1}$ Dr.Virendra K. Sharma, Professor \& Head, Department of Ophthalmology, Sri Aurobindo Medical College and \\ Postgraduate Institute, Indore, India ${ }^{2}$ Dr. Abha Verma, M.S. Assistant Professor, Department of Ophthalmology, ${ }^{3}$ Dr. Ena \\ Samuel, M.S. Senior resident, Department of Ophthalmology, ${ }^{4}$ Dr. Sapan Palod, M.S. Senior resident, Department of \\ Ophthalmology. All are affiliated with Sri Aurobindo Medical College and Postgraduate Institute, Indore, MP, India
}

Address for Correspondence: Dr Virendra K. Sharma, Email: Dr.virendra.k.sharma@gmail.com E-20 Rishi nagar, Ujjain, M.P. India

\begin{abstract}
Aims \& Objectives: It is a prospective study to determine expediency, astigmatism correction and recurrence following a modified conjunctival autograft surgical procedures in double pterygium. Material \& Methods: Equal sized conjunctival grafts were taken from the opposite pterygium of the same eye and anchored with 10-0 nylon sutures. Postoperative correction of astigmatism, visual acuity and recurrence recorded in 14 eyes of 13 patients. Results: Full correction of astigmatism in 6 cases and mean $76.9 \%$ corrected in all cases, with subsequent improvement of visual acuity of one or two lines of Snellen's chart. No recurrence recorded till 13 months. Discussion: ECA is a single time procedure, reducing hospital stay, cost and total duration of morbidity by half, with advantages of minimal tissue loss, sparing of superior conjunctiva on both nasal and temporal side and avoidance of bare sclera from the donor site of graft. Conclusion: ECA is better option in double pterygium particularly in cases of scarcity or diseased conjunctiva.
\end{abstract}

Keywords: Double Pterygium, Conjunctiva, Astigmatism, Autograft

\section{Introduction}

Pterygos, 'little wing' (from the Greek) is a triangular fibrovascular subepithelial ingrowth of degenerative bulbar conjunctival tissue over the limbus onto the cornea [1]. Bilateral pterygia are not uncommon among agricultural field workers and rural population of tropical regions and desert because of higher exposure of UV-B radiation [2, 3]. They are having relatively more horrendous look with higher degree of refractive error due to astigmatism and impending danger of encroaching visual axis resulting into grievous visual impairment. There are many schools of thought [4] regarding the ideal medical and surgical management of pterygia. Pterygium larger than $3 \mathrm{~mm}$ causing cosmetic menace, inducing astigmatism or obstructing visual axis resulting in diminution of vision are the indications for surgery[5]. Operative management requires conjunctival graft from superior temporal as well superior nasal regions, subsequently leaving large bare sclera when operated in single step. Alternatively done

Manuscript received: $1^{\text {st }}$ Sept 2015

Reviewed: $12^{\text {th }}$ Sept 2015

Author Corrected: $20^{\text {th }}$ Sept 2015

Accepted for Publication: $27^{\text {th }}$ Sept 2015 in two stages, at interval of 3 weeks to 3 months resulting in twofold multiplication of hospital stay, cost, physical and mental anguish. Situation becomes more intricate in wants of conjunctival graft in cases of conjunctiva scarring, dry eye and functional filtering bleb. Amniotic membrane graft is another option to cover bare sclera but having potential hazards of heterogeneous tissue transplant.

Authors have evaluated a modified operative technique for double pterygia by exchange of ipsilateral conjunctival graft from both sides of pterygia, without loss of tissue or leaving bare sclera, as a single procedure on the basis of clinical facts that: 1 . Pterygium is a disease of sub-conjunctival tissue of unknown aetiology and not of conjunctiva 2 . In rotational conjunctival graft technique bare sclera is covered by the same conjunctiva after 90 or 180 degree rotation with comparable results; hence bare sclera after excision of pterygium can be covered by conjunctiva taken from other side pterygium.

\section{Materials and Methods}


Participants: This study was carried out in observance with the Ethics Committee of Sri Aurobindo Medical College and Postgraduate Institute, Department of Ophthalmology, Indore during period of January 2014 to March 2015. Written and informed consent was taken from all patients.

Patients of double pterygia seen at the Ophthalmology Department of SAIMS medical college and Post Graduate Institute, who were considered to be inappropriate for conventional conjunctival auto grafting, were operated by a modified surgical procedure, which the authors describe as Exchanged Conjunctival Autograft (ECA). There were 28 conjunctival grafts performed on 14 eyes of 13 patients.

Methods: Detailed clinical examination of all cases done under diffuse light and slit lamp examination that includes best corrected visual acuity (BCVA) determination after retinoscopy, estimation of degree of keratometric astigmatism by measuring curvature of cornea with keratometer, refractive astigmatism by retinoscopy and measuring length and width by calipers to know grade of pterygium. All parameters were noted during postoperative period at regular intervals e.g. on $1^{\text {st }}$ day, $1^{\text {st }}$ week, $1^{\text {st }}$ month and every 3 month. Follow up done for a period of 13 months to notify recurrence.

Surgical Intervention: In each case, peribulbar along with sub-conjunctival anesthesia $2 \%$ lignocaine with adrenaline 1:200,000 were administered. Exposure facilitated by self retaining wire speculum. Markings made for incision for conjunctival flaps of equal sizes on both sides, though nasal pterygium was found slightly larger. To start with conjunctiva from upper and lower border of nasal pterygium incised up to the cornel attachment. The conjunctiva vertically cut at temporal end by joining both horizontal incisions and dissected by a Bard Parker no. 15 blade, up to the limbus. The fibrovascular tissue underlying the conjunctival flap was removed and conjunctival graft prepared (figure No.1); this will be used to cover scleral bed on temporal side afterwards. The scleral bed is prepared for receiving conjunctival graft by removing subconjunctival tissue and cauterization of bleeding vessels.

Same procedure performed on the pre-marked ipsilateral bulbar conjunctiva covering over pterygium on the temporal side. (Figure No.2) A free graft was obtained from temporal pterygium by vertical incision with Bard Parker no. 15 blade at the limbal end. Care was taken not to include Tenon tissue while preparing the graft. The graft was sutured to the conjunctiva surrounding the scleral bed with 10/0 interrupted nylon sutures on nasal side. (Figure No.3) Nasal conjunctival graft was detached in similar fashion and sutured on scleral bed on temporal side. (Figure No.4)

The head of the pterygium was dissected from the cornea up to the limbal margin and excised using Westcott scissors. The superficial keratectomy with a crescent knife performed (Figure No.5) to clean corneal bed of the pterygium.

Post operative management includes steroid with antibiotic drops supplemented with lubricant drops four times a day for seven days. Doses were tapered gradually depending on discomfort and injection. Nonabsorbable sutures were removed after three weeks of surgery. The follow-up continued for thirteen months. Postoperative symptomatic and clinical recovery noted. Visual acuity, best corrected visual acuity, keratometry and degree of astigmatism, complications and signs of recurrences noted and maintained record at each follow up visit on $1^{\text {st }}$ week, $1^{\text {st }}$ and $3^{\text {rd }}$ month. A closed watch kept on recurrence till 13 months.

Figure1: Nasal pterygium: limbal based conjunctival graft dissected

Figure 2: Temporal pterygium: limbal based conjunctival graft dissected

Figure 3: Excised temporal conjunctival graft placed on nasal scleral bed

Figure 4: Excised nasal conjunctival graft placed on temporal scleral bed

Figure 5: Superficial keratectomy done

Figure 6: Final appearance after surgery 


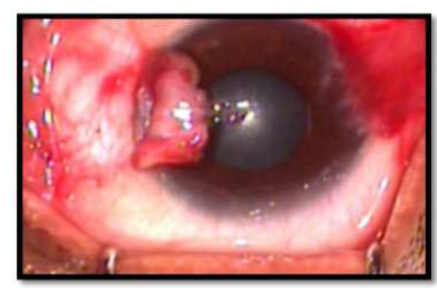

Figure1

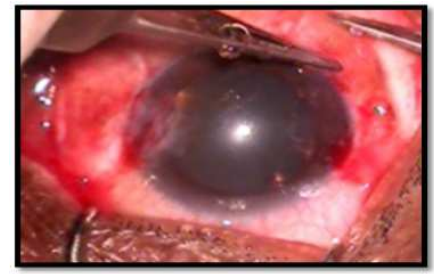

Figure 4

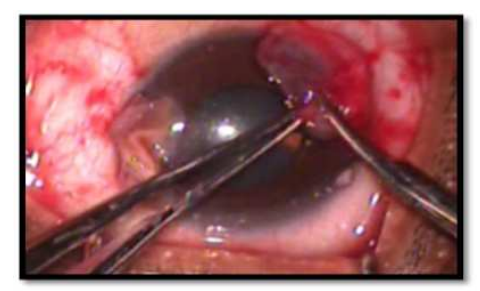

Figure 2

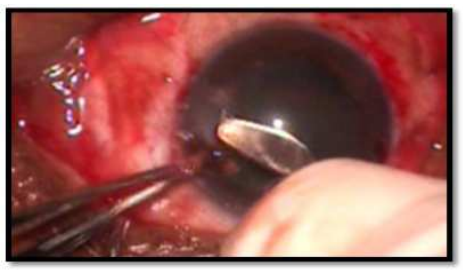

Figure 5

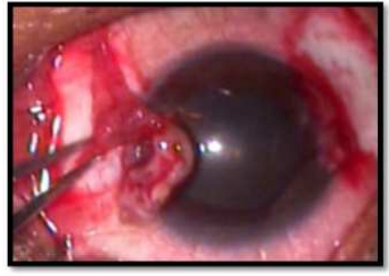

Figure 3

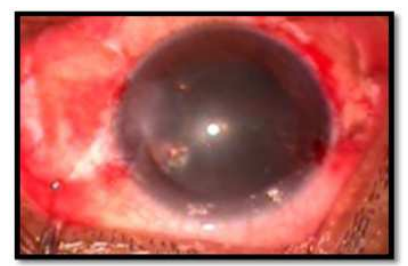

Figure 6

In one case of bilateral double pterygium other eye was operated at an interval of 6 weeks.

\section{Results}

Post-operative visual outcomes and complications studied and amplitude of astigmatism measured. The mean follow-up period was 394 days (11.7-13.9 months). Mean age was 53.7 years $( \pm 13.6$ years), with males 9 and 4 females. Double pterygia are usually of higher grades. There were all primary pterygia, in which six of grade 4 , four of grades 3 and grades 2 each; two with nuclear sclerosis grade II and one with trabeculectomy done in past.

Table.1: Comparison of pre-operative and post operative keratometric astigmatism in Diopter showing correction at different periods

\begin{tabular}{|c|c|c|c|c|c|c|c|}
\hline Case no. & Grade & $\begin{array}{l}\text { Pre -op. } \\
\text { in Diopter }\end{array}$ & $\begin{array}{l}\text { Post-op. } \\
\mathbf{1}^{\text {st }} \text { day }\end{array}$ & $\begin{array}{l}\text { Post-op. } \\
\mathbf{1}^{\text {st }} \text { week }\end{array}$ & $\begin{array}{l}\text { Post-op. } \\
\mathbf{1}^{\text {st }} \text { month }\end{array}$ & $\begin{array}{l}\text { Post-op. } \\
\mathbf{3}^{\text {rd }} \text { month }\end{array}$ & $\begin{array}{l}\text { Improvem } \\
\text { ent } \\
\text { Diopter } \\
\text { in }\end{array}$ \\
\hline 1 & 2 & 0.75 & Nil & Nil & Nil & Nil & 0.75 \\
\hline 2 & 4 & 3.25 & 1.50 & 1.5 & 1.00 & 1.00 & 2.25 \\
\hline 3 & 2 & 1.00 & 0.25 & 0.25 & 0.25 & 0.25 & 0.75 \\
\hline 4 & 4 & 4.50 & 1.25 & 1.0 & 0.5 & 0.5 & 4.00 \\
\hline 5 & 3 & 2.25 & 0.25 & Nil & Nil & Nil & 2.25 \\
\hline 6 & 2 & 0.50 & Nil & Nil & Nil & Nil & 0.50 \\
\hline 7 & 4 & 3.50 & 1.25 & 1.25 & 1.25 & 1.00 & 2.50 \\
\hline 8 & 3 & 2.75 & 2.25 & 2.00 & 1.75 & 1.75 & 1.00 \\
\hline 9 & 4 & 4.00 & 1.5 & 1.5 & 1.00 & 0.75 & 3.25 \\
\hline 10 & 3 & 1.75 & 0.5 & 0.5 & Nil & Nil & 1.75 \\
\hline 11 & 3 & 2.25 & 1.00 & 1.00 & 0.75 & 0.75 & 1.50 \\
\hline 12 & 2 & 0.50 & Nil & Nil & Nil & Nil & 0.5 \\
\hline 13 & 3 & 1.25 & 0.25 & Nil & Nil & Nil & 1.25 \\
\hline 14 & 4 & 3.25 & 1.5 & 1.5 & 1.5 & 1.25 & 2.00 \\
\hline Total & & 31.5 & 11.5 & 10.5 & 8.00 & 7.25 & 24.25 \\
\hline $\begin{array}{c}\text { Mean } \\
\text { astigmatism }\end{array}$ & & $2.25 \mathrm{D}$ & $0.82 \mathrm{D}$ & $0.75 \mathrm{D}$ & $0.57 \mathrm{D}$ & $0.52 \mathrm{D}$ & 1.73 \\
\hline $\begin{array}{c}\text { Mean \% } \\
\text { astigmatism }\end{array}$ & & $100.0 \%$ & $36.4 \%$ & $33.3 \%$ & $25.3 \%$ & $23.02 \%$ & $76.98 \%$ \\
\hline
\end{tabular}


Astigmatism: Pre-operative mean astigmatism of 14 eyes was 2.25 D (ranges from 0.5 D to 4.5D), which was reduced to mean 0.52 D (ranging from nil to 1.75 D); (Table No.1). Thus showing an improvement of astigmatism of $76.98 .0 \%$ $(1.73 \mathrm{D})$. On $1^{\text {st }}$ postoperative day mean astigmatism recorded in all case was $0.82 \mathrm{D}(36.4 \%)$; which shows that maximum correction (63.6\%) occurred immediately after surgery. (Table No. 2 ).

Visual acuity: Six cases were fully corrected, attained unaided 6/6 vision out of which full correction of astigmatism noticed in three cases on the $1^{\text {st }}$ post-operative day. Significant unaided improvement in vision- 2 lines and 1 line on Snellen's chart noticed in five and three cases respectively (Table No.3). Maximum share of improvement was observed immediately after surgery, on $1^{\text {st }}$ post-operative day. Degree of correction of astigmatism and subsequent improvement in vision is related to size of pterygium.

There was no recurrence and no significant postoperative complications encountered. One case has conjunctival cutthrough which required re-suturing. Symptomatic discomfort with conjunctival congestion remained for 1 week in 5 cases and by $2^{\text {nd }}$ week all were symptom free. In two cases grafts stayed mildly injected up to 1 month. (Table No. 4)

Cosmetic appearance was remarkable in all cases. No sign of any operative intervention was visible by the end of 3 months in most of cases.

Table 2: Number of cases having keratometric astigmatism in Diopter, pre-operative and post operatively

\begin{tabular}{|l|l|l|}
\hline Astigmatism & Pre-op number of cases & Post-op number of cases \\
\hline $0.0-1.0 \mathrm{D}$ & 4 & 6 \\
\hline $1.25-2.0 \mathrm{D}$ & 2 & 2 \\
\hline $2.25-3.0 \mathrm{D}$ & 3 & Nil \\
\hline $3.25-4.0 \mathrm{D}$ & 4 & Nil \\
\hline$>4 \mathrm{D}$ & 1 & Nil \\
\hline Total & $\mathbf{1 4}$ & $\mathbf{8}$ \\
\hline
\end{tabular}

Table No 3: Number of cases grouped on basis of visual acuity observed

\begin{tabular}{|l|l|l|}
\hline Visual acuity & Pre-operative number of cases & Post-operative number of cases \\
\hline 6/6 to 6/12 & 3 & 7 \\
\hline 6/18 to 6/36 & 4 & 5 \\
\hline 6/36 to 6/60 & 5 & 1 \\
\hline 6/6o to 3/60 & 2 & 1 \\
\hline Total & $\mathbf{1 4}$ & $\mathbf{1 4}$ \\
\hline
\end{tabular}

Table No 4: Post-operative complications observed at different periods in 14 eyes of 13 patients

\begin{tabular}{|l|l|l|l|l|l|}
\hline Observations & $\mathbf{1}^{\text {st }}$ day & 1week & 1month & 3months & 6months \\
\hline Pain/discomfort & 14 & 3 & Nil & Nil & Nil \\
\hline Injection & 14 & 5 & 2 & Nil & Nil \\
\hline Recurrence & Nil & Nil & Nil & Nil & Nil \\
\hline Graft displacement & 1 & Nil & Nil & Nil & Nil \\
\hline Cut-through & 1 & Nil & Nil & Nil & Nil \\
\hline Re-suturing & 1 & Nil & Nil & Nil & Nil \\
\hline Granuloma & Nil & Nil & Nil & Nil & Nil \\
\hline
\end{tabular}




\section{Discussion}

Medical management of double pterygia is disappointing, leaving only surgical available option for larger than $3 \mathrm{~mm}$ lesions, approaching to pupil and / or cosmetically unacceptable, associated with more than 1 $\mathrm{D}$ of astigmatism resulting to blurring of uncorrected vision. An ideal procedure must include minimum tissue loss, short and eventless convalesce period, good cosmetic result and absence of recurrence.

As it is a new modification, comparison of this technique can only possible with the procedures already in practice. A conjunctival autograft technique involves obtaining an autograft, usually from the superiortemporal/nasal bulbar conjunctiva, and suturing the graft over the exposed scleral bed after excision of the pterygium.

Double pterygium can be operated as two stage procedure; so all the parameters - surgical time duration, hospital stay, cost and possible complications are twofold multiplied. In single sitting procedure a large bulbar conjunctival graft from superior nasal as well as temporal are taken, leaving behind bare area of quite higher dimensions which heals in longer time. Conditions become hazardous in cases of xerotic, scarred conjunctiva or a glaucomatous bleb. In ECA no exposed sclera is left at the site of host conjunctival graft. After removing sub-conjunctival fibrovascular tissue, scleral beds are covered by the conjunctiva taken from the opposite pterygium. It is a single stage operation thus halves the cost and time. Preservation of bulbar conjunctiva is a distinct advantage.

Correction of astigmatism: Astigmatism depends on the size, duration and whether pterygium is single or double. Double pterygia are of longer duration, larger sizes, and having higher degree of astigmatism attributed to flattening of horizontal meridian due to stretching of sub-epithelial fibrovascular tissue; removing of which results is rectification of astigmatism and improvement of vision. Fong KS et al [6] in 1998 revealed that astigmatism of $1.0 \mathrm{D}$ or more was seen when the pterygium exceeded $3.5 \mathrm{~mm}$ beyond the limbus. This study confirms that pterygium excision induces a reversal of pterygium related corneal flattening. A strong correlation was also found between the horizontal extent of pterygium encroachment and astigmatic change following surgery [7]. We also observed postoperative changes in astigmatism of 0.62 , 1.55, and 2.8 D in Grade II, III, and IV respectively which had $0.68 \mathrm{D}, 2.05 \mathrm{D}$ and $3.7 \mathrm{D}$ astigmatism preoperatively. Mean improvement of astigmatism was $76.98 \%$.

Wu PL et al [8] (2009) found that pterygium surgery produces improvements in visual acuity, decrease in refractive spherocylinder power along with $3 \mathrm{~mm}$ of significant difference in topographic irregularity and topographic astigmatism postoperatively.

Visual outcomes: Effect on vision is independent of the graft fixation technique used [9] instead; it is influenced by factors such as the size and location of the pterygium which are responsible for inducing astigmatism. In double

pterygium astigmatism is quite noteworthy and that too is because of distortion induced by pterygium. On releasing the drag by excision of pterygium, astigmatism diminishes resulting into improvement of vision on very next day of surgery. Visual improvement is noticeable because ametropia was due to higher astigmatism which is corrected.

Cosmetic results: Aesthetic result is admirable by this procedure, with added advantage of reduced postoperative duration by half. There is no exposed tissue to promote inflammation, and patients achieve a good appearance very quickly, within 4-6 weeks. Graft is inconspicuous by the end of the month in many cases.

Risk of recurrence: Conjunctival autograft procedure if properly performed appears to carry a low risk of recurrence rates although reported incidences are 2 to 40 percent in several prospective studies. Graft that was too thick and did not cover the limbus, incomplete elimination of fibrovascular tissue, deficient dissection of pterygium head and displacement of graft were blamed for recurrence, but statically recurrence do not depends on the way of adherence of graft; which may be glyctin / nylon suture, fibrin glue or blood clot. Earlier the age of occurrence and fleshy pterygium carry larger risk.

Starck and coworkers [10] stress the importance of careful dissection of Tenon's tissue from the conjunctival graft and recipient bed; Lawrence W. Hirst, from Australia recommends using a large incision for pterygium excision and a large graft and has reported a very low recurrence rate with this technique [11].

It is argued that conjunctival graft from opposite 
pterygium will not be effective because it is from pathological condition but conjunctival rotational graft $[12,13]$ were found to have comparable results in relation with recurrence and post-operative complications. In the present series no recurrence observed, till the mean 381 days follow up. Double pterygia are usually large and in elderly patients. Large conjunctival graft kept in place by meticulous suturing under microscope; in comparatively older age are the possible reasons for non-recurrence.

\section{Conclusion}

Exchange Conjunctival auto grafting is a useful technique for all types of pterygia with minimal tissue loss without risk of exposing sclera and subsequent scarring. It has added advantage of single time procedure resulted in hospital duration, cost and discomfort by halves. No bare sclera left so reduced pain and risk of infection, particularly when there is need to preserve the superior conjunctiva for cataract and filtering bleb. Marked improvement in vision occurs because of correction of astigmatism.

\section{Funding: Nil}

Conflict of interest: None.

Permission of IRB: Yes

\section{References}

1. By Jack J. Kanski, MD, MS, FRCS, FRC Ophth and Brad Bowling, FRCS Ed(Ophth), FRC Ophth $7^{\mathrm{TH}}$ Edition 163.

2. Mackenzie FD, Hirst LW, Battistutta D and Green A: Risk analysis in the development of pterygia. Ophthalmology 1992 Jul; 99(7): 1056-61.

3. Taylor HR, West S, Munoz B, et al. The long term effects of visible light on the eye. Arch Ophthalmol 1992;110:

99-104-
4. Isyaku Mohammed, Treatment of pterygium. Annals of African Medicine Vol. 10, No. 3; 2011

5. Lawrence W Hirst, The Treatment Of Pterygium Survey of Ophthalmology March-April, 2003Volume 48, Issue 2, Pages 145-180

6. Fong KS, Balakrishnan V, Chee SP, Tan DT. Refractive change following pterygium surgery. CLAO J. 1998 Apr; 24(2):115-7.

7. Chourasia P, Mehta AD, Kumar P. Comparison of Astigmatism Before and After Pterygium Surgery. IJHSR. 2014; 4(3): 97-102

8. Wu PL, Kuo CN, Hsu HL, lai CH. Effect of pterygium surgery on refractive spherocylinder power and coneal topography. Ophathalmic Surg Lasers Imaging.2009 Jan-Feb;40(1):32-7

9. Alp BN, Yanyali A, Ay GM, Keskin O.Conjunctival rotation autograft for primary pterygium.ophthalmologica.2002 Sep-Oct:216(5):3336.

10. Starck T, Kenyon KR, Serrano F. Conjunctival autograft for primary and recurrent pterygia: surgical technique and problem management. Cornea. 1991;May;10(3):196-202.

11. Hirst LW, Sebban A, Chant D. Pterygium recurrence time. Ophthalmology1994; Apr;101(4):7558.

12. Dadeya S, Malik KP, Gullian BP. Pterygium surgery: conjunctival rotation autograft versus conjunctival autograft. Ophthalmic Surg Lasers 2002 Jul-Aug;33(4):269-74.

13. Jap A, Chan C, Lim L, Tan DT. Conjunctival rotation autograft for pterygium. An alternative to conjunctival autografting. Ophthalmology 1999 Jan;106(1):67-71.

\section{How to cite this article?}

Sharma VK, Verma A, Samuel E, Palod S. Exchange conjunctival autograft in double pterygium. Int J Med Res Rev 2015;3(9):947-952. doi: 10.17511/ijmrr.2015.i9.176. 